\title{
ANALYSING EDUCATIONAL CAMPAIGN'S OUTCOME IN DONATION-BASED CROWDFUNDING: SOCIAL CAPITAL AS A DETERMINANT FACTOR
}

\author{
Nur Adyani binti Sabarudin \\ Universiti Kebangsaan Malaysia, Malaysia \\ Suhaili binti Alma'amun \\ Universiti Kebangsaan Malaysia, Malaysia \\ Riayati Ahmad* \\ Universiti Kebangsaan Malaysia, Malaysia
}

\begin{abstract}
A new financing alternative, known as crowdfunding, has expanded rapidly. Not all crowdfunding projects or campaigns can successfully reach the desired funding amount. Many studies have shown that social capital is a determinant of crowdfunding success, and some of it could be applied to the education domain. This study investigates the influence of the multidimensional social capital on the donation-based crowdfunding within the scope of educational campaigns belonging to higher education institutions students. This study uses the primary data extracted from the Skolafund crowdfunding site, a specialised third-party platform for higher education. This study, using the theory of multidimensional social capital as the theoretical foundation, develops a logit model linking all three social capital dimensions. The findings imply that only two social capital dimensions, namely structural and relational, are significant factors influencing the crowdfunding success likelihood. This study also finds that campaigns with lower funding targets are more likely to succeed. The practical implications of this study suggest the students should leverage their social capital to increase the fundraising amount. Higher education institutions also should consider to set up their crowdfunding platforms quickly or encourage students to utilise a third-party platform, such as Skolafund.
\end{abstract}

Keywords: Crowdfunding, Donation, Education, Malaysia, Social Capital.

Received: 20 October 2020

Accepted:10 May 2021

https://doi.org/10.33736/ijbs.3764.2021

\section{INTRODUCTION}

In this increasingly challenging economic environment, many countries have reduced public spending on higher education (Jacob \& Gokbel, 2018). Universities face budget cuts and shift costs onto students by raising tuition fees and other costs related to academic programmes (Kendall et al., 2020). The dramatic increase and expensive tuition fees pressure students financially (Llorente et al., 2015). Students are required to obtain additional loans or taking on additional work to overcome the financial burden (Kendall et al., 2020). This is also the case for Malaysia (Mohd

\footnotetext{
- Corresponding author: Centre for Sustainable and Inclusive Development (SID), Faculty of Economics and Management, Universiti Kebangsaan Malaysia, 43600 Bangi, Selangor, Malaysia; Tel: +6012- 9057804; Email: riayati@ukm.edu.my
} 
Fuad, 2019). The allocation for public universities has been reduced to 70 per cent since 2017 . The other 30 per cent of the university budget must be covered through self-generated income (Abdullah, 2017). Even though the Minister of the Ministry of Higher Education Malaysia (MoHE) said that the tuition fees for domestic students remain the same, a hike in tuition fees seems inevitable. The universities are negotiating for approval to review the tuition fees, enabling them to increase fees gradually over time or adjust tuition charges to students' socioeconomic background (Abdullah, 2017). University students in Malaysia can obtain student loans provided by the National Higher Education Fund Corporation (PTPTN) or zakat (almsgiving) to ease the financial burden (Mohammed, 2011; Muhammad Haffiz \& Hairunnizam, 2017; Patmawati, 2008).

However, students worldwide are taking full advantage of crowdfunding. They are now turning to the donation-based crowdfunding to raise fund for their studies. They raise money not limited only to tuition fees but also for the accommodations, charitable efforts, internships, research, specific educational endeavours, stipend, and study abroad programmes. In June 2016, a Malaysian student studying at Al Azhar University in Egypt applied for funding on the Skolafund platform. He managed to get RM9147 in 30 days, exceeding the target amount of RM7,800. The fund was used for living expenses since his Majlis Amanah Rakyat (MARA) loan was only sufficient to pay for his tuition fees (Skolafund, 2018).

Crowdfunder, Indiegogo, and Kickstarter, running on a reward-based system, as well as GoFundMe, which is donation-based crowdfunding, have become funding sources for educational campaigns and projects. Educational campaigns on these crowdfunding platforms mix with other numerous unrelated campaigns. Besides, specific crowdfunding sites for educational projects are also available, such as Experiments and Skolafund, which are third-party platforms or crowdfunding platforms belonging to the universities and colleges.

However, not all crowdfunding campaigns or projects can successfully reach the desired funding amount. It is due to a problem known as information asymmetry. It is also the case for educational related crowdfunding campaigns. Crowdfunding has been used to obtain financial support from interested supporters to fund the proposed ideas or projects. Crowdfunding model involves three parties, namely the fundraisers proposing the ideas or projects, funders deciding to support the ideas or projects financially, and the crowdfunding sites connecting fundraisers and funders. The crowdfunding sites receive a percentage of the amount raised during the fundraising (Belleflamme et al., 2015; Ordanini et al., 2011). However, due to the information asymmetry the funders have limited information about the proposed ideas or projects, eventually affecting the amount of money contributed by them (Colombo et al., 2014; Vismara, 2016; Zheng et al., 2014).

Therefore, past studies have been carried out to find a way to overcome this problem. They concern about determinants of the crowdfunding success that can reduce the information asymmetry. One of the determinants drawing attention from the research community is social capital. Social capital is defined as the interaction, relationship, and understanding between individuals built on certain values, which can increase the quantity and quality of cooperation within the organisation to achieve the same goal (Nahapiet \& Ghoshal, 1998). Social structures, social activities, repetitive group activities, such as frequency of meeting, informal gatherings, social and family relationship, 
and social contacts of individuals, are the sources in which social capital is embedded (Davidsson \& Honig, 2003; Kang et al., 2017; Nahapiet \& Ghoshal, 1998; Zheng et al., 2014). These sources can be regarded as 'social networks'. Extended family, community-based, or organisational relationships can provide social networks (Bourdieu, 1986; Coleman, 1988; Loury, 1987), indicating the strength of ties (Davidsson \& Honig, 2003) that finally benefit an individual or social unit (Zheng et al., 2014), such as in the form of financial support (Kang et al., 2017). The social capital theory refers to the ability to extract benefits from social networks (Portes, 1998). The use of social networks benefits the crowdfunding in the sense that they connect fundraisers with fans, friends, and potential funders, who are willing to provide information as well as financial supports. By providing information about the fundraisers, it is able to reduce the information asymmetry (Vismara, 2016).

Concerning the crowdfunding, Facebook and Twitter are social networking sites that are commonly incorporated into the crowdfunding (Madrazo-lemarroy et al., 2019). Apart from these social networking sites, social networks are also specifically built within the crowdfunding community to show support to other members within the same platform (Colombo et al., 2014; Lehner, 2013). Studies on social capital and crowdfunding have focused too much on the impact of Facebook, Twitter, and any social networks serving the same purpose. Previous studies show disagreement on the impact of social networks (Madrazo-lemarroy et al., 2019). Some studies imply that social networks give a positive impact to crowdfunding success (Courtney et al., 2016). Meanwhile, others find that the funding amount received through crowdfunding is not dependent on the use of social networks (Agrawal et al., 2015; Ahlers et al., 2015).

The weakness of the existing studies is that they do not take into account other social capital dimensions, which also contribute to the campaign success, according to Zheng et al. (2014) and Madrazo-lemarroy et al. (2019). The social capital dimensions, or commonly known as the multidimensional social capital, refer to the clusters of the main facets of social capital (Nahapiet \& Ghoshal, 1998). The theory suggests that the social networks in which individuals are embedded can facilitate resource exchanges and knowledge sharing among the individuals through three dimensions, namely the structural dimension, relational dimension, and cognitive dimension (Nahapiet \& Ghoshal, 1998). Hence, the studies on social capital and crowdfunding have been extended by introducing the multidimensional social capital theory to the crowdfunding literature (see Zheng et al., 2014; Madrazo-lemarroy et al., 2019). The same theory has also been selected as the theoretical foundation for this paper.

Another weakness of the existing studies is that they also attempt to reveal the relationship between social networks and crowdfunding activities, mainly focussing on the social capital of entrepreneurs (Kang et al., 2017). Thus, it is not surprising to find that social capital is widely adopted in reward, lending, and equity-based crowdfunding literature, which are common types of crowdfunding platforms used by entrepreneurs. On the other hand, the scope of this study is crowdfunding campaigns for education, which commonly appear in the donation-based crowdfunding as non-profit activities. Hence, this leads to the following research question - Does multidimensional social capital also influence the success likelihood of the educational campaigns or projects in donation-based crowdfunding? This study attempts to examine students' multidimensional social capital that theoretically influences the success of the campaigns in 
answering the research question. This study expects that all three social capital dimensions are associated with a higher success likelihood.

This paper contributes to the crowdfunding literature in two ways. First, it extends the previous studies on the crowdfunding by exploring the donation-based crowdfunding. Second, it can be considered as the first empirical study applying social capital theory in crowdfunding for the education domain. The study is significant since it highlights the successful or the failure of the educational campaigns from a specialised third-party platform. Hence, from the policymaking point of view, findings from this paper shed some light on the crowdfunding as an alternative solution to ease the burden of government funding for higher education institutions.

The remainder of this paper is organised as follows: first, a literature review of current studies about crowdfunding aiming to determine the social capital factors associated with campaign success is presented. Second, the research model is introduced, and the construction of its corresponding hypotheses is revealed. Third, the empirical analysis is presented. Findings, as well as their implications for future research and research limitations, are in the discussion section. The conclusion section concludes this paper.

\section{LITERATURE REVIEW}

\subsection{What is crowdfunding?}

Crowdfunding is differentiated into four models - donation, reward, lending, and equity-based crowdfunding (Agrawal et al., 2011; Ahlers et al., 2015; Belleflamme et al., 2014). The donationbased model is similar to charity in which people raise fund for personal or specific charitable causes, and donors receive no rewards. On the other hand, the reward-based model allows people to contribute to projects and receive non-financial rewards in return. Lending-based crowdfunding, sometimes known as peer-to-peer (P2P) lending, debt-based or loan-based, enables an individual to obtain either interest-free or interest-based loans from investors. Meanwhile, in equity-based crowdfunding, investors fund start-ups companies in return for equity (Davis, 2011).

Crowdfunding behaves differently from other financial intermediaries due to several features. First, fundraisers or project owners present their projects online in a standardised and comprehensive way, making search relatively easy. Second, there is less monitoring involved since it allows small financial transactions to enable wide participation with limited downside risk; hence, reducing the need to monitor the daily activities compared to the traditional funding. Third, it provides information on what others have done and tools to communicate with each other (Agrawal et al., 2015). The centre of the crowdfunding is the infrastructure of information and communication technology (ICT). It means, to attract small contribution from a large crowd, crowdfunding is empowered by social media communication over the internet (Lehner, 2013). In terms of campaign types, the crowdfunding initiatives range from music, fashion, games as well as education, which is the focus of this paper.

\subsection{Asian based crowdfunding}


In 2018, the global crowdfunding market was valued at USD10.2 billion and was forecasted to almost triple by 2025 (Statista, 2019a). The volume of funds raised through crowdfunding worldwide in 2017 by types showed that most of the funds were generated through P2P lending (USD25 billion). USD5.5 billion was generated through reward and donation-based crowdfunding globally, while USD2.5 billion was generated through equity-based crowdfunding (Statista, 2019d). North American platforms raised roughly half of the global crowdfunding volume in 2017, with a total amount of USD17.2 billion. Asia raised more than Europe, with USD10.5 and 6.5 billion, respectively (Statista, 2019c).

China raised the highest volume of funds in 2017, globally. Chinese crowdfunding platforms raised USD358.3 billion in 2017, which accounted for 86 per cent of the USD416.7 billion raised in that year globally. The US platforms raised the second-highest volume of funds, amounting to USD42.8 billion, while the UK platforms raised the third-highest volume of funds, amounting to USD7.9 billion. Concerning the Asian countries, Japan, Singapore, Indonesia, South Korea, India, and Malaysia raised USD348.7 million, 190.62 million, 80 million, 1.1 billion, 268.6 million, and13.73 million, respectively (Statista, 2019b).

The crowdfunding activity in Western is marked with reward-based crowdfunding as the most dominant model. However, in Asian countries, donation-based crowdfunding and other forms, such as P2P and equity-based, are more relevant (Maracine, 2019). Malaysia is one of the first countries in Southeast Asia to give regulatory approval for equity-based crowdfunding. To date, there are 10 registered equity-based crowdfunding and 11 P2P crowdfunding in Malaysia (Securities Commission of Malaysia, 2019).

\subsection{Education and crowdfunding}

Prior studies showed that donation and reward-based crowdfunding had been used to raise fund for educational campaigns or initiatives, ranging from operational expenses, research, scholarship, student-proposed project, and tuition fees (Ingram et al., 2016; Siva, 2014). Ingram et al. (2016) conducted a case study of CrowdUni, a donation-based crowdfunding platform housed within a large North American research university, to get a comprehensive idea about university crowdfunding platform. They observed that CrowdUni aims to raise small fund for projects affiliated with the university and engages young alumni in the goings-on in the university by making small donations via CrowdUni. In terms of the governance structure, the platform and the people running it form part of the University's Alumni and Development Office. An operational unit within the university must administer the raised fund to ensure that the fund is used for the intended purpose. The individuals running the project campaigns or modules are known as Project Ambassadors, and only projects that have a link to the university can crowdfund using the platform. Meanwhile, Siva (2014) found that crowdfunding platforms have become an alternative research funding source for scientists to face the increasing competition and diminishing sources of public funding. These studies lacked theoretical foundation and statistical results, but they were sufficient for an exploratory study. Mohd Firdaus et al. (2017) reviewed the social networks as the advantages of online crowdfunding, which is used to secure grants for academic research at universities. However, if they are not able to estimate their network size and have no idea on how to tap the right crowd to be their potential funders, their social networks are not able to help them to achieve the target fund. Unfortunately, this study was a literature review only. There was no empirical 
study carried out to investigate the crowdfunding success determinant of the related educational campaign worldwide or Asian-based. Therefore, to understand this phenomenon, this study relies on the literature on social capital and crowdfunding, carried out in the context of other types of crowdfunding campaigns, as explained in the next subsection.

\subsection{Social capital and crowdfunding}

The social capital theory has been incorporated into the crowdfunding literature to explain crowdfunding success. The theory explains networks that individuals rely on (Bruton et al., 2014). There are three players involved in crowdfunding transactions, namely the funders, the fundraisers, and the crowdfunding platforms (Belleflamme et al., 2014; Madrazo-lemarroy et al., 2019; Mollick, 2014; Schwienbacher, 2018). Funders have limited information about the fundraisers and quality of the campaigns or projects due to information asymmetry. Eventually, it leads to uncertainty and the trustworthiness issue, which can decrease the confidence of the funders to support the projects (Colombo et al., 2014; Vismara, 2016; Zheng et al., 2014). Thus, Vismara (2016) argued that social networks could help to reduce information asymmetry and consequently, improve the confidence of the funders (Zheng et al., 2014).

Even though Colombo et al. (2014) also agreed that social networking sites serve this purpose, they believed social capital could be differentiated into internal and external social capital. The former is the social networks, specifically built within the crowdfunding community. Each crowdfunding platform has its crowdfunding community. They are a group of fundraisers using the same crowdfunding platforms, and they usually support other fundraisers' projects by playing a role as early backers (Colombo et al., 2014) and giving feedback to other fundraisers (Lehner, 2013). The latter is the social networks, established outside a crowdfunding platform (family, friends, and contacts on social media, such as Facebook, Twitter, and LinkedIn) (Colombo et al., 2014). Colombo et al. (2014) contended that contributions received in the very first stage of a crowdfunding campaign reduce uncertainty, and the internal social networks of fundraisers normally provide early contributions.

According to Nahapiet and Ghoshal (1998), social capital is a multidimensional concept. Thus, several studies examine the social capital impact on crowdfunding performance by differentiating it into three social capital dimensions, namely structural, relational, and cognitive. The structural dimension refers to the structural characteristics or general pattern of connections existing in the network, which are necessary for the social capital development and utilisation, such as network ties, network configuration, and the number of nodes or links through which the content flows (Madrazo-lemarroy et al., 2019). To simplify, social interaction and social network size are two expressions of structural dimension (Madrazo-lemarroy et al., 2019; Zheng et al., 2014). Facebook (Zheng et al., 2014; Madrazo-lemarroy et al., 2019), Twitter (Madrazo-lemarroy et al., 2019), and Weibo (Zheng et al., 2014) are among social networks that commonly used for a structural dimension of social capital. The number of Facebook's friends and Weibo's fans are found to have a positive relationship with campaign success (Zheng et al., 2014; Madrazo-lemarroy et al., 2019). Twitter, on the other hand, is positively related to Facebook but has no direct relationship with campaign success (Madrazo-lemarroy et al., 2019). 
Among network members, they share values and vision. Due to the sentiment of trust, norms, identity, and expectation, the element of reciprocity or obligation exists among themselves (Nahapiet \& Ghoshal, 1998). Reciprocity exists when a fundraiser support projects of other fundraisers. The support could be in the form of updates or comments posted during the campaign (Madrazo-lemarroy et al., 2019) or they fund or sponsor others' projects (Zheng et al., 2014; Madrazo-lemarroy et al., 2019). This dimension is known as the relational dimension. Both studies by Zheng et al. (2014) and Madrazo-lemarroy et al. (2019) showed the positive impact of relational dimension on campaign success.

The cognitive dimension refers to social capital development through shared language and narratives with affinity among individuals in a network (Nahapiet \& Ghoshal, 1998). In the crowdfunding context, it refers to the project description in the form of words, video, or picture aiming at convincing potential funders (Zheng et al., 2014; Madrazo-lemarroy et al., 2019). Funders can detect campaign or project deception or fraud by reading the project description written by the fundraisers, which is available on the crowdfunding platform (Madrazo-lemarroy et al., 2019). Cognitive dimension is also a notable factor influencing the crowdfunding campaign outcome. During the campaign, the fundraisers must provide updated information, and it has been empirically verified that this has a positive impact (Zheng et al., 2014; Madrazo-lemarroy et al., 2019).

Even though past studies are very much concerned about the effect of social networks and other determinants on crowdfunding success, according to Kang et al. (2017), the existing studies mainly focused on the social capital of entrepreneurs. It also explains why extant literature on the social factor impact is largely in the context of lending (P2P), equity, and reward-based crowdfunding.

\subsection{Social capital, charitable funding, and donation-based crowdfunding}

Crowdfunding sites are not specifically only for entrepreneurship. It can be extended to charitable funding associated with the donation-based crowdfunding model. Information asymmetry also exists in charitable funding. Thus, reducing the information asymmetry between fundraisers and donors is important since donor confidence and trust in charity is one of the major concerns for charities. In this context, fundraisers seeking donations use the same mechanism akin to entrepreneurs by leveraging their social networks to build trust, and eventually the chances of receiving a donation increase (Majumdar \& Bose, 2018).

Saxton and Wang (2014) contended little is known what drives the social-based charitable giving success. They proved that social capital is also a determinant factor in the donation-based but the context of charitable giving through Facebook. Online donors donate more to health or medically related fundraising compared to other causes except for education due to the exclusion of educational institution from the dataset. They argued their findings are applicable to crowdfunding as well since crowdfunding nowadays are boosted by social media. Their study concerning the social network, however, did not engage with the social capital theory. The sample was limited to large donor-dependent organisations operating in various fields. It was different from other studies observing the impact of the fundraisers' characteristics, including their social networks. Taking into account both studies by Majumdar and Bose (2018) and Saxton and Wang (2014), social 
capital theory is still applicable as a theoretical foundation even for donation-based crowdfunding in explaining the success determinant.

\subsection{Other determinants of crowdfunding success}

Apart from the social capital, the campaign duration is another factor to be considered and has an inverse effect. According to Colombo et al. (2014) and Mollick (2014), a long campaign duration results in less chance for success because the momentum of the crowdfunding projects tend to decrease as time passes (Mollick, 2014). According to Davies and Giovannetti (2018), in the equity-based crowdfunding context, the longer the campaign duration, the more patient the creator, the less likely the project is to succeed. It can be interpreted as impatience being a signal to early backers to provide early initial funding to kick-start a process of self-fulfilling positive expectations. Based on Aristotle's theory of persuasion, Majumdar and Bose (2018) suggested that the narration of the fundraisers is the key for receiving a donation. The presence of different persuasive appeals in a charity request increases its likelihood of receiving a donation. They found that female fundraisers are more likely to receive a donation due to this factor. The target amount of money that the campaign or project seeks to raise is another factor influencing the crowdfunding success. Previous studies showed that campaigns or projects with higher funding targets are less likely to succeed (Antonenko et al., 2014; Colombo et al., 2014; Hörisch, 2015; Mollick, 2014).

Past studies have investigated the relationship between crowdfunding success and social capital to understand the extent to which the social capital in which an individual is embedded can enhance the amount of money raised in crowdfunding. However, the empirical literature has not investigated the relationship between social capital of the fundraisers and educational campaign crowdfunding success. Thus, it is particularly worth to apply the existing social capital theory in the context of crowdfunding for education.

\section{METHODOLOGY}

\subsection{Why Skolafund?}

No previous study has explained the size of crowdfunding for education in Malaysia. Various internet searches were conducted to find students and universities in Malaysia using crowdfunding until 2020. Malaysia has 20 public universities. This study found that Universiti Teknologi Malaysia was the only Malaysian public university that had set up a crowdfunding platform. However, its website was not accessible most of the time and even when it was accessible, there was no crowdfunding campaign available on the platform. Other public universities, such as Universiti Kebangsaan Malaysia, Universiti Malaya, Universiti Malaysia Pahang, Universiti Malaysia Perlis, Universiti Malaysia Sarawak, Universiti Putra Malaysia, Universiti Sains Islam Malaysia, Universiti Teknologi Mara Malaysia, and Universiti Tun Hussein Onn Malaysia, had websites for online donation, endowment, gift, or waqf (an Islamic endowment). These were considered online fundraisings, but they were not crowdfunding in this study context.

JomDonate, KrowdCap, MyStartr, PitchIN, and Skolafund were third-party platforms used by alumni or university students to raise fund for their campaigns. In terms of the number of 
campaigns, each KrowdCap, MyStartr, and PitchIN had only one or two campaigns related to the university. JomDonate and Skolafund were among the most used third-party platforms by university students. All those third-party crowdfunding platforms had mixed campaign categories on their platforms except Skolafund. Therefore, their campaigns were not limited to education. Skolafund, on the other hand, was the only platform serving higher education campaigns. It limited the fundraisers to university and college students for causes related to educational projects or campaigns. It is the only platform that can provide a sufficient sample of data for the analysis.

Skolafund is one of Asia's biggest donation crowdfunding platforms. Skolafund runs on the donation-based model and the only specialised third-party crowdfunding site for higher education students. From April 1, 2017 to September 3, 2019, 350 campaigns were launched, and 189 of them were fully funded, involving funds of RM1.6 million. The funds were contributed by 11,119 donors, benefitting 592 students from less-privileged backgrounds (Fintech News Malaysia, 2019). Skolafund allows fundraisers to share their project with people through integrated social network links, such as Facebook and Twitter, and allows comments and updates regarding the campaigns on its crowdfunding site. Students can describe their fundraising cause and the amount they hope to raise. They are required to include a copy of the university's offer letter and student card for confirmation. The campaign will then be announced on the Skolafund website for the full 30 days. Depending on the fundraising cause, funds raised will be passed directly to their respective universities or directly to the fundraisers. The former is for tuition fees campaign while the latter is for other campaign types, such as the campaign to pay for the living expenses and student mobility programmes. If the campaigns fail to reach their target, the fundraisers have the option of whether the donations will be refunded to the donors or transferred to other campaigns (with the donors' consent) (Skolafund, 2020).

\subsection{Sample and theoretical modelling}

The statistical analysis was built on a dataset of crowdfunding campaigns taken from Skolafund transparency sheet available on https://blog.skolafund.com/skolafund-transparency-sheet/. This transparency sheet contained 267 campaigns and provided information, namely student's name (campaign owner), launch campaign date, target fund, the total fund raised, the campaign status either it is successful or vice versa, and total disbursement. However, these data were not sufficient. Thus, other data were extracted from the Skolafund's platform, namely the number of comments, updates, and social media usage. Fourteen campaigns were removed from the list since no information from the Skolafund website were available. Thirty-five campaigns initiated by groups were also removed since gender was also included as a control variable in this study. Besides, ten campaigns were removed, which acting as outliers. In the end, there were 208 usable crowdfunding campaigns between January 20, 2015 to December 26, 2018 for logit regression analysis. The descriptive statistics of the campaigns and campaign owners are shown in Table 1.

This study used the multidimensional social capital theory to develop a logit model linking all three social capital dimensions (social media shares as a proxy for structural dimension, update and comments as proxies for relational dimension, and the number of words as a proxy for cognitive dimension) with the campaign success likelihood. Campaign characteristic that is the target fund in Ringgit Malaysia (LnTARGET), expected to influence the campaign success, was included as a control variable in the model. Even though the campaign duration was included in previous studies, 
this study excluded this variable since the duration for all campaigns in the data set were 30 days. At the fundraiser level, the student gender (GENDER) was included as a control variable.

This study used the following logit model to analyse determinants of the crowdfunding education campaign success. The logit model was applied in this study since the response variable or regressand is a binary variable (Gujarati \& Porter, 2009). Besides, this study modified this model from the original model used in Zheng et al. (2014) and Colombo et al. (2014). Equation 1 is the logarithm of the probability ratio of outcome campaign $=1$ to that of outcome campaign $=0$.

$$
\begin{aligned}
& \log \left(\frac{\operatorname{Pr}(\text { SUCCESS })=1)}{\operatorname{Pr}(\text { FAIL })=0}\right)=\beta_{0}+\beta_{1} \text { SHARE }+\beta_{2} \text { COMMENTS }+\beta_{3} \text { UPDATES }+ \\
& \beta_{4} \text { WORDS }+\beta_{5} \operatorname{lnTARGET}+\beta_{6} \text { GENDER }
\end{aligned}
$$

Table 1 describes the variables used in this study. The dependent variable is campaign success (SUCCESS). Success in the all-or-nothing crowdfunding model is reached when a project collects the capital equal to or greater than the target amount (Colombo et al., 2014). Hence, the dependent variable is a binary variable, which was coded as equal to 1 if the project met the targeted funding amount at the campaign closure. This crowdfunding success measure has been used in previous crowdfunding research (see Belleflamme et al., 2013; Colombo et al., 2014; Courtney et al., 2016; Mollick, 2014).

In the previous studies, social capital as the crowdfunding success determinant has been observed through the use of social networks, such as Facebook and Twitter (Belleflamme et al., 2013; Madrazo-lemarroy et al., 2019). This study hypothesised that sharing posts on Facebook or Twitter might result in a significant effect on the crowdfunding campaign success. Campaigns shared on Facebook or Twitter were coded 1 while campaigns not shared on Facebook or Twitter were coded 0 . These social networks measure has been used in Belleflamme et al. (2013). The data shows that Facebook or Twitter were the only types of social media used by the fundraisers. Hence, the hypothesis that this study would like to test is:

\section{H1: Campaign posted on social media, such as Facebook or Twitter, is more likely to succeed.}

Madrazo-lemarroy et al. (2019) included comments and updates posted and exchanged through the crowdfunding platform as proxies for the relational dimension. Updates are the number of times the fundraisers posted additional information about their campaigns on the platform. Meanwhile, comments are the total number of comments posted during the campaign. Active communication is a notable factor influencing the crowdfunding campaign outcome. Providing updated information has been empirically verified to give a positive impact (Madrazo-lemarroy et al., 2019). Hence, this study posits:

\section{H2: Campaign with higher comments is more likely to succeed.}

\section{H3: Campaign with higher updates is more likely to succeed.}

The project description can differentiate fraudulent and non-fraudulent campaigns in the form of words. It indicates that the fundraiser is more likely a deceiver if little information is given about the project, the project is written more carefully and formally, uses fewer words, verbs, and 
sentences, makes fewer typographical errors, or expresses fewer feelings (Shafqat et al., 2016). Based on Zheng et al., (2014) and Madrazo-lemarroy et al. (2019), who used words for cognitive dimension, this study posits:

\section{H4: Campaign with more words is more likely to succeed.}

Campaign with higher targeted funding amounts will be less likely to succeed in achieving the targeted funding amounts (Hörisch, 2015). Thus, this variable was included. It was logarithmised to reach normal distribution (Hörisch, 2015). Hence, this study posits:

\section{H5: Lower funding target is more likely to succeed.}

According to Majumdar and Bose (2018), female fundraisers are more likely to receive a donation. It would be interesting to investigate whether crowdfunding success varies across the fundraisers' gender since gender effect has received little attention in past studies. For the gender variable, females are coded 0 and male are coded 1 . This study posits that:

H6: Female fundraiser is more likely to succeed.

Table 1: Descriptions of Variables

\begin{tabular}{|c|c|}
\hline Variable & Measurement \\
\hline \multicolumn{2}{|c|}{ Dependent Variable } \\
\hline SUCCESS & $\begin{array}{l}\text { ' } 1 \text { ' = if the project met the targeted funding amount at the end of the } \\
\text { crowdfunding campaign } \\
\text { ' } 0 \text { ' = if the project did not meet the targeted funding amount at the end of the } \\
\text { crowdfunding campaign }\end{array}$ \\
\hline \multicolumn{2}{|c|}{ Independent Variable } \\
\hline SHARE & $\begin{array}{l}' 1^{\prime}=\text { if the campaign's information is shared via one of the following social } \\
\text { media: Facebook or Twitter } \\
' 0 \text { ' }=\text { if otherwise }\end{array}$ \\
\hline \multicolumn{2}{|c|}{ Relational dimension: } \\
\hline COMMENTS & Continuous variable (Number of comments on the crowdfunding platform) \\
\hline UPDATES & Continuous variable (Number of updates on the crowdfunding platform) \\
\hline Cognitive dime & \\
\hline WORDS & $\begin{array}{l}\text { Continuous variable (Number of words of the campaign on the crowdfunding } \\
\text { platform) }\end{array}$ \\
\hline \multicolumn{2}{|l|}{ Control Variable: } \\
\hline LnTARGET & The target amount for the project \\
\hline GENDER & $\begin{array}{l}' 1 \text { ' }=\text { if the fundraiser is male } \\
' 0 \text { ' }=\text { if the fundraiser is female }\end{array}$ \\
\hline
\end{tabular}




\section{FINDINGS}

Table 2 presents the descriptive statistics pertaining to the campaign owners. Majority of them were female (63.5\%), age within the range of 21-25 years (57.7\%) and students from public higher education institutions $(59.62 \%)$. Most of the fundraisers were students studying at Bachelor's degree level $(66.83 \%)$. This situation might be due to the students studying at Bachelor's degree level were mostly young people, not having ample financial resources, as compared to mature students, typically studying at the graduate level. In terms of the field study, the majority of them were Engineering students $(23.56 \%)$. The variables summary statistics are shown in Table 3.

Table 2: The Demographic Analysis of Campaign Owners on Skolafund Platform

\begin{tabular}{lcc}
\hline \hline Characteristics & Frequency & Percentage (\%) \\
\hline Gender & 76 & 36.5 \\
Male & 132 & 63.5 \\
Female & & \\
\hline Age & 63 & 30.28 \\
18-20 years & 120 & 57.70 \\
$21-25$ years & 23 & 11.06 \\
26-29 years & 2 & 0.96 \\
30-35 years & & \\
\hline Higher Education Institutions & 124 & 59.62 \\
Public & 63 & 30.29 \\
Private & 21 & 10.10 \\
Others & & \\
\hline Education Levels & 6 & 2.88 \\
Certificate & 33 & 15.87 \\
Diploma & 139 & 66.83 \\
Bachelor's Degree & 24 & 11.54 \\
Master's Degree & 6 & 2.88 \\
Doctoral & & \\
\hline Field of Study & 25 & 12.02 \\
Economics and Management & 16 & 7.69 \\
Education & 9 & 4.33 \\
Islamic Studies & 47 & 22.60 \\
Medicine, Dentistry, Pharmacy, and Health Sciences & 20.62 \\
Social Sciences and Humanities & 26 & 12.50 \\
Science and Technology & 12 & 5.77 \\
Information Science and Technology & 4 & 1.92 \\
Law & 49 & 23.56 \\
Engineering & &
\end{tabular}

Table 3: Variables Summary Statistics

\begin{tabular}{lccccc}
\hline \hline Variable & Observation & Mean & Standard Deviation & Min & Max \\
\hline SUCCESS & 208 & .5865385 & .4936422 & 0 & 1 \\
SHARE & 208 & .3942308 & .4898638 & 0 & 1 \\
COMMENTS & 208 & 4.326923 & 7.1956 & 0 & 45 \\
UPDATES & 208 & .1586538 & .6658126 & 0 & 6 \\
WORDS & 208 & 416.1827 & 197.3953 & 65 & 1023 \\
TARGET & 208 & 5560.75 & 4725.943 & 350 & 38000 \\
GENDER & 208 & .3653846 & .4826996 & 0 & 1 \\
\hline \hline
\end{tabular}


Table 4 reports the logit regression results, running using Stata 11. This study used robust standard errors. Overall, this model is statistically significant $(p$-value $=0.0000)$, indicating a good model fit. This study also employed Wald tests to gauge the improvement in the explanatory power of the models. Variance inflation factors (VIFs) were calculated, and all values were below the threshold of 10 , indicating there is no multicollinearity problem in this study.

As shown in Table 4, SHARE significantly influences the crowdfunding campaign success at $5 \%$ significant level. Meanwhile, COMMENTS, UPDATES, and LnTARGET significantly influence the crowdfunding campaign success at $1 \%$ significant level. In contrast, no significant effect of GENDER and WORDS can be found.

The findings of this study do not support $\mathrm{H} 1$ in which campaigns are more likely to succeed when they are shared on social media. The odds ratio for SHARE indicates that students who did not share their campaigns on Facebook or Twitter are 0.3267 times more likely to succeed than those who shared their campaigns on social media.

Concerning COMMENTS and UPDATES, every unit increase in COMMENTS and UPDATES makes one's odds of having a successful campaign 1.305 and 6.046 higher, respectively. In other words, every unit increase in COMMENTS and UPDATES increases the odds of having a successful campaign by 30.5 and 504.6 per cent, respectively. Thus, $\mathrm{H} 2$ and $\mathrm{H} 3$ are supported.

Results imply that the only social capital dimension that was not a strong and consistent predictor was relational. WORDS have no significant impact on the likelihood of a successful campaign even though it indicates that an increase in a word increases the odds of having a successful campaign by 0.1 per cent. Thus, $\mathrm{H} 4$ is not supported.

The findings of this study also support H5. Every unit increase in LnTARGET (in RM) makes one's odds of having a successful campaign 0.26 lower or decreases the odds of having a successful campaign by 74 per cent. This study also confirms that gender has no significant impact on campaign success or failure. Thus, H6 is not supported.

Table 4: Logit Regression Results

\begin{tabular}{llc}
\hline \hline Variable & Coefficient & Odds Ratio \\
\hline SHARE & $-1.118199^{* *}$ & .3268679 \\
& $(.5375325)$ & \\
COMMENTS & $.2665956^{* * *}$ & 1.305395 \\
UPDATES & $(.0614021)$ & \\
& $1.799476^{* * *}$ & 6.046476 \\
WORDS & $(.6331127)$ & \\
& .0011439 & 1.001145 \\
LnTARGET & $(.0011752)$ & \\
& $-1.347629^{* * *}$ & .2598556 \\
GENDER & $(.3674757)$ & \\
& -.3867324 & .6792729 \\
Overall Evaluation Model: & $(.3521986)$ & \\
$\quad$ Log-likelihood & -100.31315 & \\
$\quad$ LR Chi-square & 81.46 & \\
$\quad$ Probability>Chi-square & 0.0000 &
\end{tabular}




\begin{tabular}{cc} 
Degree of Freedom (df) & 6,201 \\
Pseudo $R^{2}$ & 0.2888 \\
Sample Size (n) & 208 \\
\hline \hline Note: Robust SEs in brackets; $* * * p<0.01, * * p<0.05 ; * p<0.1$.
\end{tabular}

\section{DISCUSSION AND IMPLICATIONS}

This study focuses on the association between students' multidimensional social capital and the crowdfunding educational campaign success likelihood. Previous studies find that the structural dimension of the social capital variable is associated with campaign success; nevertheless, this is not the case in this study. Surprisingly, there is an absence of positive impact of social media sharing. One possibility may be due to Facebook friends are different from 'true friends'. It is stated in the study by Sisler (2012) in the context of donation-based crowdfunding for medical expenses. Since not all Facebook friends are 'true friends', therefore, they do not easily trust the fundraisers and abuse of internet fundraising could be their main concerns.

The negative impact of the structural dimension could be understood when the argument from Colombo et al. (2014) is taken into account. They argued that Facebook is a friendship-based social capital; and for entrepreneurs, they usually have their professional social capital (such as LinkedIn). The social contacts of entrepreneurs on Facebook could be not much different from their social contacts on LinkedIn as Colombo et al. (2014) found the results are indifferent to the use of LinkedIn, Facebook, or both. Hence, it should be noted that the social circle of entrepreneurs is slightly different from the social circle of students. Even though entrepreneurs and students use the same social media to share their crowdfunding efforts, such information reach different types of the target group. This study views that these plausible explanations are also applicable to Twitter.

On the other hand, this study suggests that the relational dimension of social capital is important for the success likelihood of crowdfunding educational campaigns. The effect of the relational dimension of social capital is consistent with previous studies (Madrazo-lemarroy et al., 2019). The crowdfunding platform helps students connect their campaigns to social media, such as Facebook and Twitter, to solicit donations from family, friends, and even strangers. However, the use of social networks on these social media does not seem to enhance the campaign success likelihood. Surprisingly, updates and comments on the Skolafund crowdfunding platform, representing the relational dimension of the social capital, give a positive impact on crowdfunding campaigns success. Another plausible explanation is that donors trust updates and comments on the crowdfunding platform more than information shared on Facebook and Twitter. Neither the cognitive dimension nor gender exhibit significant coefficients. The insignificant result for gender is in line with Kang et al. (2017). This study shows that the number of students seeks to raise a fund using crowdfunding is an influential determinant. Skolafund follows an 'all-or-nothing' model; thus, students pledge money is only collected if the goal is reached. This study implies that selecting realistic project goals that are not too low and not too high, as suggested by Mollick (2014), is somewhat very important.

The paper has interesting implications for students, universities, and crowdfunding platforms. This study suggests that students should not rely exclusively on their social media connections. They 
should actively post updates and comments about their campaign during and after the fundraising period. Higher education budgets have always been under pressure, even in Malaysia. With the growth of the internet, universities and students can reduce their dependencies on public funding in the form of subsidy and scholarship.

This paper has some limitations that call for future research. First, this paper does not differentiate the impact of Facebook and Twitter, which has been done in Madrazo-lemarroy et al. (2019). Second, the paper uses data from Skolafund. Caution should be taken in generalising this study's results to other crowdfunding platforms used for education campaigns since they could operate on a different policy. Third, a data set that includes educational campaigns from Malaysian universities' crowdfunding is almost unavailable. The only university that has a crowdfunding platform is Universiti Teknologi Malaysia (UTM). However, the subsidy link provided is not accessible most of the time when this study is being conducted. Universiti Kebangsaan Malaysia (UKM) has online fundraising, which has some crowdfunding features; however, the number of campaigns is too small, which is not sufficient for an empirical study. Hence, this would not allow this study to observe the effect of multidimensional social capital from multiple platforms.

In light of the broad diffusion of social media, the growing interest in crowdfunding and the potential to reach large audiences efficiently, students are increasingly integrating their social capital into their fundraising efforts. Social capital is a study area that has a much greater opportunity for intervention. From a theoretical perspective, understanding the link between social capital and the donation-based crowdfunding campaigns success, in the context of education, represents an important area of future research. From the public policy perspective, donation-based crowdfunding can solve many educational related issues, which are due to public funding constraints.

The 2015 UK Alternative Finance Industry Report shows that the total volume of online alternative business funding in Malaysia reached USD3.36 million in 2015, growing from USD667,009 in 2013 to $\$ 1.03$ million in 2014 , with an average growth rate of $56.7 \%$ per annum over the period from 2013 to 2015 (Zhang et al., 2016). From the figure, the total market volume of Malaysian online alternative finance was dominated by donation-based crowdfunding. It is accounted for $92.4 \%$ of the total Malaysian market, raising a total of USD4.68m.

Donation-based crowdfunding has been a long-established means of finance for non-profit ideas and projects (Lehner, 2013). Educational campaigns offering no reward in return to the donors are associated with this type of crowdfunding model. Concerning the educational crowdfunding campaigns, Skolafund is one of the most popular third-party platforms among higher education students in Malaysia.

\section{CONCLUSION}

Motivated by the recent development in crowdfunding, this study examines the role of multidimensional social capital on the crowdfunding platform for the financing of higher education students. Specifically, this study finds that crowdfunding campaign success is strongly related to the structural and relational dimensions of social capital. The findings suggest that managers of 
crowdfunding platform should consider designing tools that facilitate effective communication between the funders and fundraisers to enhance the funding success likelihood. Besides, the government should offer incentives to those donating through crowdfunding to raise public awareness in using crowdfunding platform as an intermediary for donation. This study has a limitation in which the study only examines data from a single crowdfunding website focusing on the financing of higher institutions tuition fees. Therefore, future studies may examine the data from other donation-based crowdfunding platforms to confirm the success factors identified in this study.

\section{ACKNOWLEDGEMENT}

This study is funded by Dana Skim Geran Penyelidikan Universiti Kebangsaan Malaysia (Project code: GUP-2016-001).

\section{REFERENCES}

Abdullah, D. (2017). Public universities and budget cuts in Malaysia. International Higher Education, 91, 15-17. https://doi.org/10.6017/ihe.2017.91.10129

Agrawal, A., Catalini, C., \& Goldfarb, A. (2011). Friends, family, and the flat world: The geography of crowdfunding. (NBER Working Paper No. 16820). National Bureau of Economic Research. https://doi.org/10.3386/w16820

Agrawal, A., Catalini, C., \& Goldfarb, A. (2015). Crowdfunding: Geography , social networks, and the timing of investment decisions. Journal of Economics \& Management Strategy, 24(2), 253-274. https://doi.org/10.1111/jems.12093

Ahlers, G. K. C., Cumming, D., Günther, C., \& Schweizer, D. (2015). Signaling in equity crowdfunding. Entrepreneurship: Theory and Practice, 39(4), 955-980. https://doi.org/10.1111/etap.12157

Antonenko, P. D., Lee, B. R., \& Kleinheksel, A. J. (2014). Trends in the crowdfunding of educational technology startups. TechTrends, 58(6), 36-41. https://doi.org/10.1007/s11528014-0801-2

Belleflamme, P., Lambert, T., \& Schwienbacher, A. (2013). Individual crowdfunding practices. Venture Capital, 15(4), 313-333. https://doi.org/10.1080/13691066.2013.785151

Belleflamme, P., Lambert, T., \& Schwienbacher, A. (2014). Crowdfunding: Tapping the right crowd. Journal of Business Venturing, 29(5), 585-609. https://doi.org/10.1016/j.jbusvent.2013.07.003

Belleflamme, P., Omrani, N., \& Peitz, M. (2015). The economics of crowdfunding platforms. Information Economics and Policy, 33, 11-28. https://doi.org/10.1016/j.infoecopol.2015.08.003

Bourdieu, P. (1986). The forms of capital. In J. G. Richardson (Ed.), Handbook of Theory and Research for the Sociology of Education (pp. 241-258). Greenwood Press.

Bruton, G., Khavul, S., Siegel, D., \& Wright, M. (2014). New financial alternatives in seeding entrepreneurship: Microfinance, crowdfunding, and peer-to-peer innovations. Entrepreneurship Theory and Practice, 39(1), 1-18. https://doi.org/10.1111/etap.12143

Coleman, J. S. (1988). Social capital in the creation of human capital. American Journal of 
Sociology, 94, S95-S120. https://doi.org/10.1086/228943

Colombo, M. G., Franzoni, C., \& Rossi-Lamastra, C. (2014). Internal social capital and the attraction of early contributions in crowdfunding. Entrepreneurship Theory and Practice, 39(1), 1-26. https://doi.org/10.1111/etap.12118

Courtney, C., Dutta, S., \& Li, Y. (2016). Resolving information asymmetry: Signaling, ndorsement, and crowdfunding success. Entrepreneurship: Theory and Practice, 41(2), 265290. https://doi.org/10.1111/etap.12267

Davidsson, P., \& Honig, B. (2003). The role of social and human capital among nascent entrepreneurs. Journal of Business Venturing, 18(3), 301-331. https://doi.org/10.1016/S0883-9026(02)00097-6

Davies, W. E., \& Giovannetti, E. (2018). Signalling experience \& reciprocity to temper asymmetric information in crowdfunding evidence from 10,000 projects. Technological Forecasting and Social Change, 133, 118-131. https://doi.org/10.1016/j.techfore.2018.03.011

Davis, A. (2011). Beyond the banks: Innovative ways to finance Britain's small businesses. National Endowment for Science, Technology and Arts, United Kingdom. https://media.nesta.org.uk/documents/beyond_the_banks_innovative_ways_to_finance_brit ains_small_businesses.pdf

Fintech News Malaysia. (2019, October 9). Ata Plus sees first successful equity crowdfunding exit with Skolafund. Fintech News Malaysia. https://fintechnews.my/21698/crowdfundingmalaysia/ataplus-sees-first-successful-equity-crowdfunding-exit-with-skolafund/

Gujarati, D. N., \& Porter, D. C. (2009). Basic Econometrics (5 $5^{\text {th }}$ ed.). McGraw-Hill Education.

Hörisch, J. (2015). Crowdfunding for environmental ventures: An empirical analysis of the influence of environmental orientation on the success of crowdfunding initiatives. Journal of Cleaner Production, 107, 636-645. https://doi.org/10.1016/j.jclepro.2015.05.046

Ingram, C., Vaast, E., \& Teigland, R. (2016). Corporate crowdfunding: Does being part of a university affect a platform's operations? Proceedings of the 49th Annual Hawaii International Conference on System Sciences. https://doi.org/10.1109/HICSS.2016.572

Jacob, W. J., \& Gokbel, V. (2018). Global higher education learning outcomes and financial trends: Comparative and innovative approaches. International Journal of Educational Development, 58(2016), 5-17. https://doi.org/10.1016/j.ijedudev.2017.03.001

Kang, L., Jiang, Q., \& Tan, C. H. (2017). Remarkable advocates: An investigation of geographic distance and social capital for crowdfunding. Information and Management, 54(3), 336-348. https://doi.org/10.1016/j.im.2016.09.001

Kendall, N., Goerisch, D., Kim, E. C., Vernon, F., \& Wolfgram, M. (2020). The True Costs of College. Palgrave Macmillan. https://doi.org/10.1007/978-3-030-53861-3

Lehner, O. M. (2013). Crowdfunding social ventures: a model and research agenda. Venture Capital, 15(4), 289-311. https://doi.org/10.1080/13691066.2013.782624

Llorente, R., Morant, M., \& Garrigos-simon, F. J. (2015). Crowdlearning, applying social collaboration in higher education. In Pixel (Ed.), Conference Proceedings: New Perspectives in Science Education (pp. 256-261). Padova: Webster srl.

Loury, G. C. (1987). Why should we care about group inequality? Social Philosophy \& Policy, 5(1), 249-271.

Madrazo-lemarroy, P., Barajas-portas, K., Elena, M., Tovar, L., \& Barajas-portas, K. (2019). Analyzing campaign' s outcome in reward-based crowdfunding. Internet Research, 29(22), 1-20. https://doi.org/10.1108/INTR-03-2018-0115

Majumdar, A., \& Bose, I. (2018). My words for your pizza: An analysis of persuasive narratives 
in online crowdfunding. Information and Management, 55(6), 781-794. https://doi.org/10.1016/j.im.2018.03.007

Maracine, R. (2019). The distinct evolution of crowdfunding strategies in Asian countries. Manager Journal, 29(1), 139-147.

Mohammed B, Y. (2011). Zakat expenditure, school enrollment, and economic growth in Malaysia. International Journal of Business and Social Science, 2(6), 175-181. https://doi.org/10.1017/S1876404511200046

Mohd Firdaus, R., Masitah, G., \& Shukor, A. R. (2017). Online crowdfunding as academic grants: A systematic literature review. Journal of Telecommunication, Electronic and Computer Engineering, 9(3-4 Sp), 187-193.

Mohd Fuad, M. S. (2019). Endowment fund (Waqf) as an answer to increasing cost in managing higher institutions. Advances in Economics, Business and Management Research, 74 (pp. 71-74). Netherland: The Alantis Press.

Mollick, E. (2014). The dynamics of crowdfunding: An exploratory study. Journal of Business Venturing, 29(1), 1-16. https://doi.org/10.1016/j.jbusvent.2013.06.005

Muhammad Haffiz, M. I., \& Hairunnizam, W. (2017). Peranan institusi pengajian tinggi dalam pembangunan pendidikan asnaf mualaf: Kajian Kes Kolej Dar al-Hikmah. Negeri Sembilan: Universiti Sains Islam Malaysia.

Nahapiet, J., \& Ghoshal, S. (1998). Capital, Social Capital, Intellectual Capital, and Organizational Advantage. Academy of Management Review, 23(2), 242-266. https://doi.org/10.2307/259373

Ordanini, A., Miceli, L., Pizzetti, M., \& Parasuraman, A. (2011). Crowd-funding: transforming customers into investors through innovative service platforms. Journal of Service Management, 22(4), 443-470. https://doi.org/10.1108/09564231111155079

Patmawati, H. I. (2008). Pembangunan ekonomi melalui agihan zakat: Tinjauan empirikal. Shariah Journal, 16(2), 223-244.

Portes, A. (1998). Social capital: Its origins and applications in modern sociology. Annual Review of Sociology, 24, 1-24. https://doi.org/10.1016/b978-0-7506-7222-1.50006-4

Saxton, G. D., \& Wang, L. (2014). The social network effect. Nonprofit and Voluntary Sector Quarterly, 43(5), 850-868. https://doi.org/10.1177/0899764013485159

Schwienbacher, A. (2018). Entrepreneurial risk-taking in crowdfunding campaigns. Small Business Economics, 51(4), 843-859. https://doi.org/10.1007/s11187-017-9965-4

Securities Commission of Malaysia. (2019). SC Registers First Property Crowdfunding Operator. https://www.sc.com.my/development/digital/list-of-registered-recognized-market-operators

Shafqat, W., Lee, S., Malik, S., \& Kim, H. (2016). The language of deceivers: Linguistic features of crowdfunding scams. Proceedings of the 25th International Conference Companion on World Wide Web (pp. 99-100).

Sisler, J. (2012). Crowdfunding for medical expenses. CMAJ : Canadian Medical Association Journal, 184(2), 123-124. https://doi.org/10.1503/cmaj.109-4084

Siva, N. (2014). Crowdfunding for medical research picks up pace. The Lancet, 384(9948), 10851086. https://doi.org/10.1016/S0140-6736(14)61661-5

Skolafund. (2018). Skolafund. https://skolafund.com/600-i-havent-had-the-worse-setbackscompared-to-some-others-but-now-i-need-to-push-myself-to-be-able-to-be-a-good-doctorthis-is-the-exposure-i-need-please-help-me-hoping-there-are-generous-hands-that-wouldkindly-help-me-achieve-thi

Statista. (2019a). Crowdfunding market size globally 2018 and 2025. 
https://www.statista.com/statistics/1078273/global-crowdfunding-market-size/

Statista. (2019b). Crowdfunding volume worldwide in 2017, by country. https://www.statista.com/statistics/1078229/global-crowdfunding-volume-worldwide-bycountry/

Statista. (2019c). Crowdfunding volume worldwide in 2017, by region. https://www.statista.com/statistics/946659/global-crowdfunding-volume-worldwide-byregion/

Statista. (2019d). Volume of funds raised through crowdfunding worldwide in 2017, by type. https://www.statista.com/statistics/946668/global-crowdfunding-volume-worldwide-bytype/

Vismara, S. (2016). Equity retention and social network theory in equity crowdfunding. Small Business Economics, 46(4), 579-590. https://doi.org/10.1007/s11187-016-9710-4

Zhang, B., Deer, L., Wardrop, R., Grant, A., Garvey, K., \& Thorp, S. (2016). Harnessing Potential: The Asia-Pacific Alternative Finance Benchmarking Report. Cambridge: Cambridge Judge Business School.

Zheng, H., Li, D., Wu, J., \& Xu, Y. (2014). The role of multidimensional social capital in crowdfunding: A comparative study in China and US. Information and Management, 51(4), 488-496. https://doi.org/10.1016/j.im.2014.03.003 